Article

\title{
When the Personal Is Always Political: Norwegian Muslims' Arguments for Women's Rights
}

\author{
Hannah Helseth \\ Centre for Gender Research, University of Oslo, 0316 Oslo, Norway; E-Mail: hannah.helseth@stk.uio.no
}

Submitted: 2 April 2018 | Accepted: 28 June 2018 | Published: 22 November 2018

\begin{abstract}
For almost two decades, the public debate about Islam in Western Europe has been dominated by concerns about the lack of gender equality in the racialized Muslim population. There has been a tendency to victimize "the Muslim woman" rather than to encourage Muslim women's participation in the public debate about their lives. This contribution to the study of discourses on Muslim women is an analysis of arguments written by Muslims about women's rights. The data consists of 239 texts written by self-defined Muslims in major Norwegian newspapers about women's rights. I will discuss two findings from the study. The first is an appeal to be personal when discussing issues of domestic violence and racism is combined with an implicit and explicit demand to represent all Muslims in order to get published in newspapers-which creates an ethno-religious threshold for participation in the public debate. The second finding is that, across different positions and different religious affiliations, from conservative to nearly secular, and across the timeline, from 2000 to 2012 , there is a dominant understanding of women's rights as individual autonomy. These findings will be discussed from different theoretical perspectives to explore how arguments for individual autonomy can both challenge and amplify neoliberal agendas.
\end{abstract}

\section{Keywords}

European Islam; feminism; Hannah Arendt; individualism; neoliberalism; Norway; public debate; traditional media; Wendy Brown; women's rights

\section{Issue}

This article is part of the issue "Gender Equality and Beyond: At the Crossroads of Neoliberalism, Anti-Gender Movements, 'European' Values, and Normative Reiterations in the Nordic Model”, edited by Lena Martinsson (University of Gothenburg, Sweden), Diana Mulinari (Lund University, Sweden) and Katarina Giritli Nygren (Mid Sweden University, Sweden).

(C) 2018 by the author; licensee Cogitatio (Lisbon, Portugal). This article is licensed under a Creative Commons Attribution 4.0 International License (CC BY).

\section{Introduction}

"It is at this point a political action to tell it like it is, to say what I really believe about my life instead of what I've always been told to say", writes Carol Hanich (1970, p. 24) in her essay with the iconic title The Personal is Political. The year is 1969 and Hanich is writing about the women's movement consciousness-raising meetings. Giving political and social problems their proper name was part of the success of the women's movement. The rhetorical move of making the personal political has been a dominant strategy for several political movements, where counter-publics have been used to give idioms, notions, and narratives and raise the consciousness of marginalized groups in society (Andersen, 2014; Brown, 1995;
Fraser, 2000). Thus, it is not surprising that the present analysis of Muslims' arguments for women's rights in the Norwegian media sphere show that "I" was frequently used and the use of personal anecdotes and narratives was a dominant rhetorical strategy to address racism and women's oppression. What is more surprising is that, across different positions and religious affiliations, from conservative to nearly secular, and across the timeline, from 2000 to 2012, there is a dominant understanding of gender equality as individual autonomy.

For two decades the western public debate about Islam has been dominated by concerns about the lack of gender equality in the racialized Muslim population. There has been a tendency to describe "Muslim women" rather than encourage participation by the women who 
are under scrutiny (Abu-Lughod, 2013; Ahmed, 2011; Göle, 2013; Scott, 2007; van Es, 2016). Studies of the Norwegian and Dutch media discourse of migrant and Muslim women have found that the growing attention paid to "Muslim" women's perceived lack of emancipation and the accusation that Islam oppresses women have turned "being oppressed" into a stigma (van Es, 2016). The discourse of the oppressed Muslim woman creates a counter stereotype of the "Western woman" as modern, progressive, secular, highly educated and active in the labour market (Benn \& Jawad, 2003, pp. 1-17). This juxtaposition indicates that the discourse of the Muslim woman in the Norwegian and Western-European context forms the general public discourse about gender equality and women's rights (Scharff, 2011).

The data for my research is every text written by selfdefined Muslims in op-eds or in the debate section in major Norwegian newspapers about women's rights between 2000 and 2012. The archive consists of 239 texts. In this article, I have focused on two findings from a larger study of topics concerning the controversies about women's rights and Islam in the media debate (Helseth, 2017). The main aim is not to cover all arguments and topics concerning women's right in the text archive, but to discuss the rhetorical use of the personal narrative when arguing for women's rights and the topos of individual autonomy.

This article is divided into six sections, including this introduction. The second section is a description of the methodology. The third section shows that Muslims are being personal when they argue for women's rights through their use of experience, family background and anecdotes and that, simultaneously, they are met with both explicit and implicit demands to represent Muslims as a group. I argue that these two factors-being personal, almost private, and representing a collectivecreate an ethno-religious threshold in the Norwegian media debate. In the fourth section, I show that individual autonomy is an important topos in arguments for women's rights. In the fifth section, I discuss how the tendencies towards individualization of the public debate and the topos of personal autonomy can both challenge and amplify the neoliberal agenda. Finally, in the sixth section I make some concluding remarks.

\section{Methodology}

I have analysed texts written by Muslims about women's rights that were published in national or regional newspapers between 2000 and 2012. Through the use of a Norwegian media database, Retriever, I have collected texts using five criteria: (1) the texts are written by a person who claims to be a Muslim or represent a Muslim organization. Thus, I apply a broad definition of "Muslim". There is no objective definition of being a Muslim, and the boundaries of the definition are one of the contested issues in the discussion of the category Muslim (Leirvik, 2009; Roald, 2004). (2) The 239 items are written texts.
This criterion excludes interviews and participation in TV debates because I want to analyse arguments as close to the writers' own words and agendas as possible. (3) The texts are published in a regional or national newspaper, which means an editor before publication has approved them. (4) The topic of the text is women's rights, as the writer understands them. If the writer claims to be arguing for women's rights, the text is part of the sample. The topics of the texts include, for example, honour-killing, forced marriage, critiques of the media stereotype of the "Muslim" woman as oppressed, patriarchal social control, racism, Islamic feminism, arguments for Islam as a women-friendly religion and arguments that perceive Islam as oppressive. There is great heterogeneity in the material. (5) The texts were published during the timeframe of 2000 to 2012.

Following these five criteria, I have constructed an archive of 239 texts. On the one hand there are substantial advantages in creating a body of data because it makes it possible to be quite specific about how Norwegian Muslims argue for women's rights in the media sphere. On the other hand, it limits the perspective. This is not a study of the totality of the media debate about Islam, women's rights or the multicultural society. And the archive is not representative of all Norwegian Muslims' views on women's rights. Rather, the archive consists of Muslims' arguments for women's rights that the mainstream media was willing to publish, and this makes it possible to analyse what could be seen as both implicit and explicit demands in the media debate.

The text was coded using qualitative software to reveal patterns of idiom and argumentation. There are several methods to analyse texts in the social sciences, and the reasons here for applying a version of discourse analysis inspired by Carol Bacchi's question "what is the problem represented to be?" (Bacchi, 2009), the WPR approach, and classical rhetorical theory (Aristoteles, 2006/340 BC; Kjeldsen, 2006; Rosengren, 2008) are based on the data material and my research interests. The texts as a genre are rhetorical, and a rhetorical theory gives the opportunity to preserve the writer's intention ("ethos") and the emotional investment and intensity of the argument ("pathos"), while giving a social context to the arguments by an analysis of "topoi". Topoi are the plural form of topos, which translates from Greek as "place". In the analysis, it is used as the mental place that gives arguments their authority. Topoi can be understood both in terms of which persons and ethos have a legitimate right to participate in the discourse, which arguments (logos) are valid and which normative ideals are seen as unquestionably good. The possibility of persuading somebody depends on you agreeing on something, and this something is "topoi". Aristoteles $(2006 / 340$ BC) states that there are three modes of persuasion, through ethos, pathos and logos. In this article, the topoi of ethos arguments are particularly relevant. Ethos is the speaker's trustworthiness; the performance, the mode of speaking, but also the social back- 
ground, clothes and dialect. An ethos argument presupposes that the speaker understands what is convincing for the audience to whom she is speaking. Studying patterns of ethos arguments, of how the writers position themselves in the texts, signals what the readers presumably find convincing. An examination of which arguments seem convincing reveals demands on ethos, on who she needs "to be" in order to be heard and what she needs to say to convince the group to whom she is speaking. Thus, the analysis has the potential to reveal social structures and hierarchies in the society where the speaker performs her arguments.

Carol Bacchi's (2009) WPR approach presupposes that we are governed by "problematisations". Thus, to analyse what the problem is represented to be is a way of understanding the underlying discourses of what is seen as a political or social problem. These "problematisations" form the imagined and implemented political solutions in society. Thus, by analysing the problem representations in the arguments, we gain clarity about the dominant discourses that form the ways in which we speak or think about what is a good and just society.

In conclusion, I have used a rhetorical analysis of topoi and an understanding taken from Bacchi's WPR approach to analyse the dominant ethos in the arguments, the politics of the personal, and the topos of personal autonomy. In the following sections, I translate all quotes from the texts.

\section{The Politics of the Personal}

There are several indications that point to individualization when Muslims argue for women's rights. Firstly, the analyses of the timeline show that the classical multiculturalism argument (Modood, 2011), which assumes that cultural traditions and practices should have special protection because they are a part of a minority culture, disappears in 2004. This indicates that the struggle for rights as a minority group is not central to the argumentation after 2004 and that the individual is the preferred entity to argue for rights. Secondly, 239 texts are coded in qualitative software that gives the opportunity to do word counts, and "I" was used 1307 times. Literally, this is to take words out of context, but it is nevertheless an indication that the use of first-person narratives is important in the texts, and this leads to the third point. The analyses of argumentation show that first personnarratives and personal experience are used to highlight racial discrimination and women's oppression. Personal biographies, family relations and religious beliefs seem like significant parts of the arguments' topoi (Helseth, 2017, pp. 151-164). They must to some degree have the legitimate right to speak. I will give one example. Ambreen Perez (2010, p. 23) writes about social control by the ethnic majority in Norway:

I have experienced sarcastic comments like: "It would have been better to see you in a mini-skirt than with that cloth on your head", "You are not western anymore, now you are one of those "gardinfolka" ("curtain people"). "Paki-whore" is another example that ethnic Norwegian women who convert to Islam have heard.

The frequent use of "I", the disappearing argument of classical multiculturalism and the use of personal experience together signal an individualization of the Norwegian multicultural debate. But there is also a tendency to implicitly and explicitly indicate that the "I" represents Muslims as a group.

One of the criteria for the text archive is, as mentioned, is that you are a Muslim and write from a position of being part of the Muslim community. Some of the writers use this positioning to legitimize a critical stance towards their own group. Lily Bandehy (2009a, p. 47) argues for a hijab ban and writes:

I am a refugee from Iran who grew up in a Muslim family. Islam is a part of my identity and it is a part of me, and nobody can accuse me of suffering from Islamophobia. But both many modern Muslims and I wish to ban the hijab in the public sphere in Norway.

Bandehy signals her Muslim identity to legitimize her ethos as a speaker for the group. She uses this ethos to represent "modern Muslims" and to indicate that she is an insider and knows what the group wants. She also uses the ethos to avoid accusations of "Islamophobia". The group identity is not only used to criticize Islam in the text archive, but also to defend it from generalization, par example when Shabana Rehman $(2009$, p. 10) writes: "I am a radical Muslim" as her, answer to a claim that Islam in itself is destructive. Bushra Ishaq (2010, p. 56) describes the stigmatization and discrimination she has experienced because she is a publicly well-known Muslim.

In addition to these examples of group representation, there are two modes of argumentation that reveal the problem with the ethos of representing Muslims as a group: the accusation of speaking "with two tongues" and to be a "coconut".

Walid al-Kubaisi (2006, p. 2) claims that Muslim spokespersons "speak with two tongues", one in which they praise acts of terror for their own group and a public voice that condemns the same actions. Shabana Rehman (2002, p. 4) accuses Pakistani men of "double standards". Again Bandehy (2009b, p. 40) accuses the politician Abid Raja of participating in a "dangerous double game". Through delegitimizing other writers' ethos, they are highlighting an ethos of truth. The use of the adjective "double" to describe the others' position makes sense as long as there is a mistrust of the Muslim group ethos in the public debate. Accusations of being duplicitous can be warranted by the lack of trust between Islamic organizations and the Norwegian media public.

The other accusation that also concerns belonging to a racialized group are the label "coconut" used by Iffit 
Quershi (2006, p. 4). Being a "coconut" implies that one has the wrong ethnic loyalty, and the argument attacks the ethos of the speaker and not the logos. The warrant of the argument as racialized is that, if they criticize their ethnic group for such things as lack of gender equality, they do it because they have internalized the negative views held by the majority society.

Both of these arguments have a questionable way of placing the emphasis on group loyalty, and that what you are is more important than what you say. The supposition is that both arguments are connected to the writer's ethnicity, or more specifically to their ethno-religious background. The reason why both labels are valid is that the accused writer has a Muslim background.

Together, the combination of the distinctive use of a personal narrative to be given a voice and an explicit and implicit demand to represent all Muslims creates what I have labelled an ethno-religious threshold for Muslims who participate in the public debate about women's rights. This threshold is unjust because it prevents parity of participation and hinders an opportunity to have a voice about matters that concern your life. White feminists who participate in the debate about violence against women are not necessarily met with demands to talk about their personal lives, and their views are not interpreted as the views of all white women, but are often seen as individual views on the situation.

The intertwining of the personal narrative and the political issue may cause and increase a particular form of argumentation by which, if the writer's personal narrative (ethos) is questioned, the political issue can also be undermined. This could lead to a self-reinforcing negative spiral, where an attack on the ethos becomes more central than what the writer is actually arguing, the logos.

Feminist and postcolonial critics have targeted the fact that some people's situated knowledge has been reduced to being singular and particular, but others' voices, perspectives and experiences have been understood as universal (Beauvoir, 1997; Mohanty, 2003; Ortner, 1972). The criticism can be summed up like this: if a person writes, talks and experiences from a marked position as an "other", then that position is seen as exceptional and one that cannot represent the human condition or universal human experience. Here, the marked position as a Muslim indicates that you should be more personal than others and at the same time seem to represent a collective identity.

\section{The Topos of Individual Autonomy}

Through the use of Carol Bacchi's (2009) methodology of asking "what is the problem represented to be?" I found that in almost all of the 239 texts the political problem was represented to be a lack of individual autonomy (Helseth, 2017, pp. 117-139). The text archive consists of a variety of positions and opinions. But whether the argument is for wearing the niqab, questioning the status of the hijab, arguments against forced marriage or against postcolonial paternalism, the problem is represented to be women's lack of individual autonomy. The writers disagree on what hinders women's individual autonomy, but they all use the same topos.

The first group of arguments describes the problem to be the lack of critique of patriarchal collective culture in the minority community, which hinders women's personal autonomy. The second group of arguments describes the problem to be the labelling of Muslim women as oppressed, which hinders personal autonomy. The first group of arguments is founded on the binary opposition between individual freedom and a collectiveoriented culture. Shabana Rehman in particular gives voice to the fight against the collective-oriented culture "where the individual barely exists" (Rehman, 2005a, p. 47) and young people pay "with their own blood" (Rehman, 2005b, p. 4) in the fight for "individual freedom"(Rehman, 2005b, p. 4.) In this group of arguments, gender equality is defined as liberation from collectiveoriented culture and religious norms. The definition of individual autonomy is the act of liberating yourself from an oppressive background.

The second group of arguments describes the binary opposition as between the right to be seen as an individual with agency and being labelled as oppressed. Ali Athar (2002, p. 34) states that for "many youths, among them girls, the opportunity to live according to their own beliefs, traditions and to be different within Norwegian society is a problem". In arguments for the right to wear the hijab, the most central is individual agency (Akran, 2004, p. 50; Alghazari, 2012, p. 23; Hassan, 2010, p. 13, 2011, p. 16; Khan, 2009, p. 22; Mahmood, 2009, p. 22; Pervez, 2010, p. 4; Raja, 2009, p. 38; Rafiq, 2002, p. 51; Tajamal, 2009, p. 3).

There are four different ways to validate the argument: (1) that women's choice of clothing is a private issue as opposed to a public concern; (2) in terms of the right to personal autonomy over your own body; (3) as a phenomenon that the majority society has problems to see as a free choice; and (4) as clothing that the writers themselves have chosen to wear.

The right to value and perform cultural and Islamic traditions is framed as a question of personal autonomy. The right to choose a way of life that contrasts with the dominant majority culture is described as a token of individual autonomy. Both groups of arguments frame the problem to be collective cultural norms. In the first group, they target patriarchal cultural and religious norms and in the second group they target the cultural norms of the majority.

\section{Neoliberal Individualism and Feminism}

In the previous three sections, I have presented the methodology of my study of how Norwegian Muslims argue for women's rights, along with two empirical findings: the ethos of the personal narrative combined with collective representation and the topos of individual au- 
tonomy. In this, section the findings will be discussed through the lens of how the individualization of the political discourse can both amplify and challenge a neoliberal agenda. A common understanding of neoliberalism is as a political economic system that:

[P]roposes that human well-being can best be advanced by liberating individual entrepreneurial freedoms and skills within an institutional framework characterized by strong private property rights, free markets and free trade. (Harvey, 2005, p. 2)

Even though this is a definition of neoliberalism that targets economic policies affecting a large number of citizens across the world, it is not the economic agenda that I wish to discuss here. Therefore, Wendy Brown's $(2005,2015)$ definition of a neoliberal rationality is more appropriate. Brown poses the question of what is new in neoliberalism and answers that it is deploying a form of governmentality "that reaches from the soul of the citizen" (Brown, 2005, p. 39). She describes neoliberalism as a form of rationality that is "extending and dissemination market values to all institutions and social action" (Brown, 2005, p. 40). Central to her definition is the notion of homo œconomicus; the embodiment of market rationality which also becomes the gold standard for human behaviour in every sphere of life. The neo in neoliberalism is, according to Brown, a change in morality, whereby all human actions, policies and political rhetoric are measured against a standard of profitability, a neoliberal economization (Brown, 2015, pp. 28-35). She states: "Within neoliberal rationality, human capital is both our "is" and our "ought" - what we are said to be, what we should be, and what the rationality makes us into through its norms and construction of environments" (Brown, 2015, p. 36).

Brown describes a rather grim vision of the future of the liberal democracy where homo œconomicus has replaced homo politicus. When liberty is relocated from political to economic life, the purpose of participating is not to develop moral autonomy and gain insights into your own views and desires; your desires are predefined by the logic of the market. Neoliberal individualism is the right to participate in a market, but without the possibility of changing the rules of competition, the goal is profit and by earning you are doing the right thing. Brown's context is the USA and she argues against the economization of every sector of society. The Norwegian context is different in the sense that we have a welfare state, even though the rhetoric of the market is having a great impact, for example, in the sphere of higher education (Hessen, 2017). However, I find her concept of neoliberal rationality and normativity fruitful in the discussion of my findings of how Norwegian Muslims argue for women's rights. I start with a discussion of the topos of individual autonomy.

Self-realization, individuality and modernity are intertwined entities, and it is tempting to suggest that Mus- lims who argue for women's rights are part of the zeitgeist of modern societies when they emphasize personal autonomy. As part of the project of modernity, your personal choices reveal your individuality and tell the story of who you are (Beck \& Beck-Gernsheim, 2002; Giddens, 1997; Gullestad, 2006). As a consequence, there is also a battle for who can be understood as a subject of free will. This battle has a particular colonial history, as Gayatri Spivak (1988/2009) shows in her influential essay in which she discusses whether there is a possibility for the subaltern to speak. Spivak describes how the British colonial regime uses the powerful discourse of saving the brown women from brown men to legitimize their occupation by banning the tradition of widow burning, sati. In consequence, the Indian woman is an object. On the other hand, the Indian nationalist argument is that Indian women are willing to die, and the self-sacrificing woman is described as a subject, a token of Indian nationalist nostalgia. Since saving the Muslim ("brown") women is still used within an imperialist and racist agenda (Abu-Lughod, 2013; Ahmed, 2011; Göle, 2013; Scott, 2007; van Es, 2016), it is understandable that Muslims in the Norwegian public debate argue for their right to agency, to be seen as modern individuals with free will. But this raises two questions: who defines what agency is? And agency over what?

Wendy Brown is critical of the dominant understanding of choice in the western hijab debate. In this debate, there is a false dichotomy between morally autonomous western women and Muslim hijab-wearing women.

The idea that Western women choose while Islamic women are coerced ignores the extent to which all choice is conditioned by as well as imbricated with power, and the extent to which choice itself is an impoverished account of freedom, especially political freedom. (Brown, 2012, p. 10)

Saba Mahmood (2005) criticizes the Eurocentric views of agency that are relentlessly tied to the political goal of personal autonomy in western feminist philosophy and studies. In Mahmood's study of conservative Egyptian Salafi women, "the western feminist" understanding of agency does not apply. Mahmood states that the desire to submit to God and undermine your own desires is not possible to understand in the feminist vocabulary of agency, which has personal autonomy as its supreme goal. These religious women want to form their selves within a collective religious frame-and this process is not deterministic but situated. The Norwegian anthropologist Christine Jacobsen (2011) uses Mahmood's thinking in her analyses of young Norwegian Muslims' selfunderstanding. These young women interpret and bend religious norms and demands into a vocabulary of choice, autonomy and authenticity, in ways that mix their demands for personal autonomy with religious norms. Jacobsen's use of Mahmood can contribute to contextualizing the demand for personal autonomy. The ideal of 
personal autonomy can be framed as a colonial idea that makes it difficult to understand Muslim women's actions and views as self-determined by using Western women's lives, experiences and ideas as an unquestionable standard against which every woman is measured. This is a valuable critique, but it does not give answers to what role personal autonomy should have in a feminist agenda for a just society.

In Anne Phillips' (2007) Multiculturalism without Culture, she states that persons have rights, not cultures or religions, and tries to formulate universal standards for a just multicultural society. Her three norms are: to protect minors from harm, to prevent physical and mental violence, and to ensure that men and women are treated as equals (Phillips, 2007, p. 34). Personal autonomy, according to Phillips, is not sufficient to ensure gender equality. She thinks that there is an embedded tension between personal autonomy and equality because people have a tendency to make choices that sustain hierarchies. The opportunity to choose has to be seen in relation to how the sum of the gender-conservative choices conforms to and amplifies gender norms and hierarchies. Choices are conditioned as well as imbricated by power, as Wendy Brown describes, and Phillips would add that they are always made within a cultural context-a context that is not static or unchangeable, but still forms our desires and the choices we make.

In the text archive, the dominant topos is individual autonomy; even the most conservative Muslims use the right to choose as a central argument. The topos of personal autonomy can be used to amplify a neoliberal agenda and can be seen as part of the tendency labelled "choice feminism" (Thwaites, 2017). Rachel Thwaites critiques the use of the choice narrative in feminism. The topos of "choice feminism" is that a woman should be able to do whatever she wants. Thus, choice feminism strives to be inclusive and not condemn individual women's choices. The problem, according to Thwaites (2017), is that this is also part of the pervasive neoliberal rhetoric of choice and it hinders a necessary political discussion of the cultural norms, political practices and economic inequalities that inform our individual choices. Even though Thwaites writes about women who choose to take their husband's name in Britain, her discussion is informative for an understanding of the topos of personal autonomy when Muslims argue for women's rights in Norway. When the topos of personal autonomy is used to understand women's rights, one needs to ask: who has agency, and agency over what? This leads to a further discussion of how feminism is understood in relation to neoliberalism in the Norwegian public debate and probably in other countries in the Global North. However, individual autonomy should not be abandoned or delegitimized as a political goal, and it could also be essential to challenge the neoliberal agenda, as I will show in the discussion of the next finding.

In Section 4, I make an argument that there is an ethno-religious threshold that is unjust because Muslims are met with demands to be both personal and at the same time seen as representing a collective. This normative judgment is based on an ideal of everyone having a right to moral autonomy. In 1944 essay We Refugees, Hannah Arendt writes about the paradoxes of being an individual and also part of the collective of Jewish refugees: "If we are saved we feel humiliated, and if we are helped we feel degraded. We fight like madmen for private existences with individual destinies" (Arendt, 1943/1994, p. 114).

In Arendt's agonistic individualism, which has also been labelled "democratic individualism" (Kateb, 1994), one can first appear as an individual when one recognizes the reciprocal right of others to do the same. "The end of the common world has come when it is seen only under one aspect and is permitted to present itself in only one perspective" (Arendt, 1998, p. 58). Arendt explicitly defends the individual voice, and what makes her theory and reflections particularly relevant to this article is that she defends the individual voice in relation to a marked identity as Jewish (Scholem \& Arendt, 1964). Her ideal for public debate is for everyone to have the opportunity to speak with a personal voice, to speak one's truth, doxa, while simultaneously being part of a collective identity as Jewish, and to claim what is universal, what should be true, good and right for all. And everyone should be able to move between these modes of argument. Arendt's individualism is far from the neoliberal rationality that has reduced a normative standard of moral autonomy to a narrow understanding of self-interest. As Arendt writes elsewhere:

As Jews we want to fight for the freedom of the Jewish people, because "If I am not for me-who is for me?" As Europeans we want to fight for the freedom of Europe, because "If I am only for me-who am I?" (cited in Butler, 2007, p. 27)

Arendt's moral autonomy is an individualism that is dependent on the social context and the collective identities that "one merely belongs to" (Scholem \& Arendt, 1964). Arendt's ideal of public debate makes it possible to examine what is wrong when racialized individuals are held responsible for the collective and are presumed to have a certain kind of loyalty to their own group. And at the same time, we must not abandon the moral responsibility to fight for freedom. In Arendt's ideal of public debate, one should be able to represent a difference without being reduced to that difference, and I argue that she can be a starting point for developing an individualism that challenges the neoliberal agenda.

\section{Conclusion}

In this article, I have presented two findings from a study of how Norwegian Muslims argue for women's rights. The first finding is that an ethno-religious threshold is created in the debate by the demand that Muslims have to 
both be personal and at the same time represent a collective, and the second finding is that the dominant foundation of the arguments for women's rights is individual autonomy. I have used Wendy Brown's definition of neoliberal rationality as a starting point for the discussion of the findings. If the topos of autonomy is not subjected to critical scrutiny of who is seen to have agency, and agency over what, it could both amplify discrimination and lead to an impoverished academic and political discourse. But, the critical scrutiny should not lead to an abandonment of the norm, but to a better understanding of the topos of individual autonomy in the public media debate about Islam and women's rights. I make an argument that Hannah Arendt's "democratic individualism" can emphasize the right to simultaneously be an individual voice, be part of a collective identity and argue for what is universally good for all. The rhetorical tool of making the personal political, as Carol Hanich (1970) argues, is a necessary and powerful political tool that has proved to be especially important for marginalized groups within society. It is crucial in the struggle for a more just society that the marginalized find their voice, but the ways in which they are given a voice and what it is possible for them to claim needs critical discussion. Hopefully, this article can be a contribution to this dialogue.

\section{Acknowledgments}

Thanks for useful comments from the editors and reviewers.

\section{Conflict of Interests}

The author declares no conflict of interests.

\section{References}

Abu-Lughod, L. (2013). Do Muslim women need saving? Cambridge, MA: Harvard University Press.

Ahmed, L. (2011). A quiet revolution: The veil's resurgence from the Middle East to America. New Haven, $\mathrm{CT}$ : Yale University Press.

Andersen, U. C. (2014). Når margin blir mainstream: forhandlinger av ekteskap, foreldreskap og slektskap i mediene (no. 483). Institutt for sosiologi og samfunnsgeografi, Det samfunnsvitenskapelige fakultet, Universitetet i Oslo, Oslo.

Akran, A. (2004, March 6). Paradoksenes debatt. Dagbladet, p. 50.

Al-Kubaisi, W. (2006, February 11). Hvem stjal Koranen, da? Klassekampen, p. 2.

Alghazari, L. (2012, June 11). Hijab som symbol. Vårt Land, p. 23.

Athar, A. (2002, July 3). Minoritet og majoritet. Klassekampen, p. 34.

Arendt, H. (1994). We, refugees. In M. Robinson (Ed.), Altogether elsewhere: Writers on exhile. London: Faber and Faber. (Original work published 1943)
Arendt, H. (1998). The human condition (2nd ed.). Chicago, IL: University of Chicago Press.

Aristoteles. (2006). Retorikk. Oslo: Vidarforl. (Original work published $340 \mathrm{BC}$ )

Bacchi, C. (2009). Analysing policy: What's the problem represented to be? Sidney: Pearson Australia.

Bandehy, L. (2009a, August 11). Farvel til hijab. VG, p. 47.

Bandehy, L. (2009b, August 28). Kamuflert islamist. VG, p. 40.

Beck, U., \& Beck-Gernsheim, E. (2002). Individualization: Institutionalized Individualism and its social and political consequences. London: Sage.

Benn, T., \& Jawad, H. A. (2003). Muslim women in the United Kingdom and beyond: Experiences and images (vol. 2). Leiden: Brill.

Beauvoir, S. (1997). The second sex. London: H. M. Parsley.

Brown, W. (1995). States of injury: Power and freedom in late modernity. Princeton, NJ: Princeton University Press.

Brown, W. (2005). Edgework: Critical essays on knowledge and politics edgework. Princeton, NJ: Princeion University Press

Brown, W. (2012). Civilizational delusions: Secularism, tolerance, equality. Theory \& Event, 15(2).

Brown, W. (2015). Undoing the demos: Neoliberalism's stealth revolution. New York, NY: Zone Books.

Butler, J. (2007). I merely belong to them [Review of the book The Jewish writings, by H. Arendt]. London Review of Books, 29(9), 26-28.

Fraser, N. (2000). Rethinking recognition: Discussion on identity politics. New Left Review, 3(May/June), 107.

Giddens, A. (1997). Modernitetens konsekvenser. Oslo: Pax.

Göle, N. (2013). Islam and public controversy in Europe. Farnham: Ashgate.

Gullestad, M. (2006). Plausible prejudice: Everyday experiences and social images of nation, culture and race. Oslo: Universitetsforl.

Hanich, C. (1970). The personal is political. In S. Firestone \& A. Koedt (Eds.), Notes from second year: Women's liberation. New York, NY: Radical Feminism.

Hassan, I. (2010, January 15). Burka og bikinimoralister. Morgenbladet, p. 13.

Hassan, I. (2011, November 14). Hijab som kvinnekamp. Morgenbladet, p. 16.

Harvey, D. (2005). A brief history of neoliberalism. Oxford: Oxford University Press

Helseth, H. (2017). Fornuft og følelser-muslimers argumenter for kvinners rettigheter i medieoffentligheten fra 2000 til 2012. Oslo: Doktorgradsavhandling i sosiologi, Det samfunnsvitenskapelige fakultet.

Hessen, D. (2017). Sannhet til salgs. Oslo: Res Publica.

Ishaq, B. (2010, May 11). Populismens fors $\varnothing$ mmelse. Dagbladet, p. 56.

Jacobsen, C. (2011). Troublesome threesome: Feminism, anthropology and Muslim's women piety. Feminist Review, 98, 65-82. 
Kateb, G. (1994). Arendt and individualism. Social Research, 61(4), 765.

Khan, H. (2009, March 10). Hun brente min hijab. Klassekampen, p. 32.

Kjeldsen, J. (2006). Retorikk i vår tid: en innføring i moderne retorisk teori ( 2 nd ed.). Oslo: Spartacus.

Leirvik, O. (2009). Kulturelle muslimar-Definisjonsmakt, hegemonikamp og religionspolitikk. Nytt Norsk Tidsskrift, 26 ER(01).

Mahmood, S. (2005). Politics of piety: The Islamic revival and the feminist subject Islamic revival and the feminist subject. Princeton, NJ: Princeton University Press.

Mahmood, S. (2009, March 13). Å brenne hijaben er krenkende, Bergens Tidende, p. 22.

Mohanty, C. (2003). Feminism without borders: Decolinizing theory, practicing solidarity. Durham: Duke University Press.

Modood, T. (2011). Multicultuarlism: A civic idea. Cambridge: Polity.

Ortner, S. (1972). Is female to male as nature is to culture? Feminist Studies, 1(2), 5-31.

Pervez, A. (2010, March 8). Vår feminisme. Aftenposten, p. 4.

Perez, A. (2010, January 22). Moralpolitiet. Aftenposten, p. 23.

Phillips, A. (2007). Multiculturalism without culture. Princeton, NJ: Princeton University Press

Quershi, I. (2006, May 24). Debattens uverdige aktører. Aftenposten, p. 4.

Raja, A. (2009, Feburary 19). Frihet til å velge hijab. Dagbladet, p. 38.

Rafiq, A. (2002, February 8). Veien til frigjøring. VG, p. 51.

Rehman, S. (2002, January 5). De skinnhellige. Dagbladet, p. 4.

Rehman, S. (2005a, December 17). Å ære eller ikke være. VG, p. 47.

Rehman, S. (2005b, October 1). Fight for freedom. Dagbladet, p. 4.

Rehman, S. (2009, April 22). Samtiden i våre hender. Aftenposten, p. 10.

Roald, A. S. (2004). Who are the muslims? Question of identity, gender and culture in research methodologies. In T. Beattie \& U. King (Eds.), Gender, religion and diversity: Cross-cultural perspectives. London: Continuum.

Rosengren, M. (2008). Doxologi: en essä om kunnskap. Retorikförlaget.

Scharff, C. (2011). Disarticulating feminism: Individualization, neoliberalism and the othering of 'Muslim women'. The European Journal of Women's Studies, 18(2), 119-134.

Scholem, G., \& Arendt, H. (1964). Eichmann in Jerusalen: An exchange of letters. Encounter, 22(1), 51-56.

Scott, J. W. (2007). The politics of the veil. Princeton, NJ: Princeton University Press.

Spivak, G. C. (2009). Kan de underordnede tale? Agora, 27(01), 40-103. (Original work published 1988)

Tajamal, H. (2009, February 13). Vi blir undervurdert. $A f-$ tenposten, p. 3.

Thwaites, R. (2017). Making a choice or taking a stand? Choice feminism, political engagement and the contemporary feminist movement. Feminist Theory, 18(1), 55-68.

van Es, M. (2016). Stereotypes and Self-representations of women with Muslim background: The stigma of being oppressed. Basingstoke: Palgrave Macmillan.

\section{About the Author}

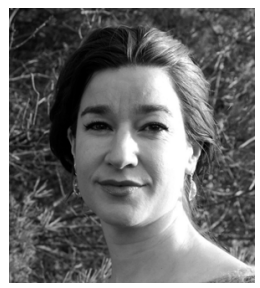

Hannah Helseth has a PhD in Sociology and is currently working as a researcher at the Norwegian centre for violence and traumatic stress studies and as a lecturer at the Centre for gender studies at the University of Oslo. 